\title{
Influence of repeated applications of glyphosate on its persistence and soil bioactivity ${ }^{(1)}$
}

\author{
Mara Mercedes de Andréa( ${ }^{(2)}$, Terezinha Bonanho Peres ${ }^{(2)}$, Luiz Carlos Luchini(2), Sheila Bazarin ${ }^{(2)}$ \\ Solange Papini(2), Marcus Barifouse Matallo ${ }^{(2)}$ and Vera Lucia Tedeschi Savoy ${ }^{(2)}$
}

\begin{abstract}
Pesticide degradation studies are essential to evaluate its impact in the environment and on non-target organisms. The effect of repeated soil applications of the herbicide glyphosate on its dissipation and on soil microorganisms was studied by radiometric and microbial techniques. Results indicated fast dissipation of the $\left[{ }^{14} \mathrm{C}\right]$-glyphosate or $\left[{ }^{14} \mathrm{C}\right]$ metabolites extractable residues (half-life of $0.92 \pm 0.29$ month), but increasing half-lives of total mineralization ranging from 2.2 to 3.4 months as the number of applications increased from 1 to 4 . No significant correlation was found between ${ }^{14} \mathrm{CO}_{2}$ production and dehydrogenase activity.
\end{abstract}

Index terms: pesticide residues, mineralization, dehydrogenases, soil treatment.

\section{Influência de repetidas aplicações de glifosato na sua persistência e na bioatividade do solo}

Resumo - Estudos sobre degradação de pesticidas são essenciais à avaliação do impacto que causam no ambiente e em organismos não-alvo. Avaliou-se o efeito de repetidas aplicações do herbicida glifosato em solo na sua dissipação e em microrganismos do solo, por técnicas radiométricas e microbianas. Os resultados indicaram dissipação rápida dos resíduos extraíveis de glifosato marcado com ${ }^{14} \mathrm{C}$ ou de metabólitos contendo ${ }^{14} \mathrm{C}$ (meia-vida de 0,92 $\pm 0,29$ mês), mas meia-vida crescente de 2,2 a 3,4 meses para mineralização total, de acordo com o aumento de 1 a 4 aplicações. Não foi encontrada correlação estatisticamente significativa entre a atividade da desidrogenase e a produção de ${ }^{14} \mathrm{CO}_{2}$.

Termos para indexação: resíduo de pesticida, mineralização, desidrogenase, tratamento do solo.

\section{Introduction}

Glyphosate [N-(phosphonomethyl)glycine] is a highly water soluble herbicide $\left(12 \mathrm{~g} \mathrm{~L}^{-1}\right)$ and insoluble in mostly organic solvent. It is mostly recommended for post-emergence in doses of the active ingredient from 0.34 to $4.43 \mathrm{~kg} \mathrm{ha}^{-1}$ (Worthing \& Hance, 1991). Nowadays it is one of the most popular herbicides not only in agriculture but also in forestry, because of its effective control of competitive vegetation and low mammalian toxicity (Busse et al., 2001). It acts by enzymatic inhibition of the shikimic acid pathway, resulting in depletion of essential aromatic amino

\footnotetext{
(1) Accepted for publication on August 24, 2003.

(2)Instituto Biológico, Av. Cons. Rodrigues Alves 1252, CEP 04014-002 São Paulo, SP, Brasil. E-mail: andrea@biologico.sp.gov.br, peres@biologico.sp.gov.br, luchini@biologico.sp.gov.br, sheibza@zipmail.com.br, solangepapini@uol.com.br, matallo@biologico.sp.gov.br, savoy@biologico.sp.gov.br
}

acids needed for plant growing and survival (Haney et al., 2000; Environmental Protection Agency, 2003). Most living organisms do not have this enzyme, which is however, ubiquitous in microorganisms (Busse et al., 2001). The amount and diversity of soil microorganisms are extremely important for soil metabolic processes, because they act on the organic matter decomposition contributing for the soil fertility (Bromilow et al., 1996; Andréa et al., 2000).

Although glyphosate is not recommended for direct application in soil, a significant amount may reach the soil during early-season or preplant applications (Haney et al., 2000). The soil half-life of glyphosate varies from few days to two or three months, and mostly, is smaller than one growing season; but, there are some reports of soil persistence for hundred and thousand days, and persistence of the phytotoxic activity for more than 19 weeks after the application (Heinonen-Tanski, 1989; Feng \& Thompson, 1990; Weber, 1994). 
It is known that glyphosate adsorbs strongly in the soil, through hydrogen bonds in organic matter and by anion exchange processes in the clay minerals, iron and aluminium oxides (Aubin \& Smith, 1992; Haney et al., 2000; Veiga et al., 2001). The role of adsorption on the glyphosate bioavailability and biodegradation is not completely conclusive, although Veiga et al. (2001) state that the adsorbed glyphosate is more persistent in the soil, because its degradation is slower than that of the free herbicide.

Besides its biological degradation in soil and water, at least transiently, glyphosate also stimulates the soil basal respiration, increases the microbial biomass (Wardle et al., 1994; Haney et al., 2000), and reduces the growth of earthworms after repeated applications (Springett \& Gray, 1992). Souza et al. (1999a, 1999b) verified that glyphosate leaching was very small in two different Brazilian soils and the soil microorganisms used the herbicide as $\mathrm{C}$ source, but the process was extremely dependent of soil moisture. However, Krzysko-Lupicka \& Orlik (1997) verified that glyphosate used as a unique source of $\mathrm{P}$ or $\mathrm{C}$ inhibited the soil fungi population and changed the strain composition, thus acting as environmental selecting agent. On the other hand, Bromilow et al. (1996) and Busse et al. (2001) did not detect differences in the microbial processes of soil treated with glyphosate among other pesticides.

Pesticide degradation studies are essential for persistence evaluation and glyphosate is classified as dangerous for the environment and highly toxic for microorganisms (Brasil, 2003; Environmental Protection Agency, 2003). A safe interval of at least 15 days is required for preharvest of crops treated with glyphosate (Brasil, 2003; Environmental Protection Agency, 2003), which means that residues might not be present in the food after this period, and glyphosate might be again applied for weed control. The objective of this work was to evaluate the effect of repeated applications of the herbicide glyphosate in soil on its dissipation and on soil microorganisms by radiometric and microbial techniques.

\section{Material and Methods}

An Ultisol soil sample from the Centro Experimental do Instituto Biológico, Campinas, SP, Brazil, was collected from 0 to $15 \mathrm{~cm}$ of the soil profile from an area without occurence of pesticide applications. Soil sample dried naturally just enough to be sieved in $2 \mathrm{~mm}$ mesh. According to determinations of the "Laboratório LAGRO", Campinas, SP, it is clayey sand and its main physico-chemical characteristics are 650,150 and $200 \mathrm{~g} \mathrm{~kg}^{-1}$, respectively, of sand, silt and clay, $\mathrm{pH}\left(\mathrm{CaCl}_{2}\right) 5.4$ and $31 \mathrm{~g} \mathrm{dm}^{-3}$ of organic matter.

The soil water maximum holding capacity (WMHC) was determined according to Frighetto \& Valarini (2000); then, $74 \mathrm{~g}$ (dry weight equivalent) portions were placed in 24 biometer flasks (Bartha \& Pramer, 1965) and had the water content adjusted to $50 \%$ WMHC. The biometer flasks remained one week in a dark chamber with controlled temperature at $25 \pm 1^{\circ} \mathrm{C}$, for reactivation of soil bioactivity. Mass of each sample was recorded for moisture correction, if necessary.

An aqueous $\left[{ }^{14} \mathrm{C}\right]$-glyphosate solution was prepared containing $372 \mu \mathrm{g}$ and $26.8 \mathrm{kBq} \mathrm{mL}^{-1}$ by mixture of Nortox ${ }^{\circledR}$ formulated glyphosate certified by the Environmental Chemistry Laboratory of Instituto Biológico as $480 \mathrm{~g} \mathrm{~L}^{-1}$ of the isopropylamine salt of glyphosate, and $\left[\mathrm{N}-\left({ }^{14} \mathrm{C}\right.\right.$-phosphonomethyl)-glycine] from Amersham International with $2.70 \mathrm{GBq} \mathrm{mmol}^{-1}$.

One week after the bioreactivation, $10 \mathrm{~g}$ soil were sampled for verification of moisture content and dehydrogenase activity. The remaining soil samples of the biometer flasks $(64 \mathrm{~g})$ were treated up to four times at fortnight intervals with $0.5 \mathrm{~mL}$ of the $\left[{ }^{14} \mathrm{C}\right]$-glyphosate solution. Each treatment consisted in $3.0 \mu \mathrm{g}$ glyphosate and $0.22 \mathrm{kBq}$ of ${ }^{14} \mathrm{C}$-glyphosate per $\mathrm{g}$ soil, which agrees with the interval of recommended doses. Soil of each six flasks received 1,2, 3 or 4 treatments, and was checked for the intended final $60 \% \mathrm{WMHC}$ after treatments. The radioactivity actually present after the treatments was determined by combustion of $(3 \times)$ approximately $0.5 \mathrm{~g}$ (dry equivalent) soil subsamples of each biometer flask in a Biological Oxidizer (Harvey OX-600), according to Andréa et al. (1997). Each group of three flasks of each treatment was studied for soil bioactivity, measured by the mineralization of $\left[{ }^{14} \mathrm{C}\right]$-glyphosate to ${ }^{14} \mathrm{CO}_{2}$ and the dehydrogenase activity at different time intervals during one or two months. The flasks were maintained in the dark at $25^{\circ} \mathrm{C}$ during all the experimental time. At the end of the first or second month, soil samples of each flask were extracted for determination of ${ }^{14} \mathrm{C}$-extractable and the soil extracted samples were examined for the ${ }^{14} \mathrm{C}$-non-extractable or bound residues for the glyphosate persistence studies.

The ${ }^{14} \mathrm{CO}_{2}$ production was verified in the $10 \mathrm{~mL}$ of the $\mathrm{KOH} 0.1 \mathrm{~mol} \mathrm{~L}^{-1}$ solution from the lateral arm of the biometer flasks which was changed at 1,2,3,5, 7 days and then weekly up to one or two months after each $\left[{ }^{14} \mathrm{C}\right]$-glyphosate application. The ${ }^{14} \mathrm{CO}_{2}$ quantification was performed by liquid scintillation counting (LSC) of 
$1.0 \mathrm{~mL}$ aliquots of the $\mathrm{KOH}$ solution of each flask (Papini \& Andréa, 2000), after addition of Bray's scintillation solution modified by Mesquita \& Rüegg (1984).

The intensity of the oxidative processes was evaluated by soil dehydrogenase activity (DHA) measurements in the soil samples after the reactivation of the biological activity prior to herbicide treatments as well as immediately, one and two months after each treatment. The procedure was basically that of Schuster \& Schröder (1990) using (3 × approximately $3 \mathrm{~g}$ (dry weight equivalent) soil subsamples. The 2,3,5-triphenyltetrazolium chloride (TTC) was used as substrate to be reduced to Formazan in presence of DHA. Formazan formation was measured by spectrophotometry at $485 \mathrm{~nm}$ (Andréa et al., 2000).

After the biomineralization studies, the amounts of ${ }^{14} \mathrm{C}$-remnant, ${ }^{14} \mathrm{C}$-extractable and ${ }^{14} \mathrm{C}$-non-extractable residues were determined in soil subsamples of each flask. The ${ }^{14} \mathrm{C}$-extractable residues were determined basically according to Andréa et al. (2001), by extraction of $(3 \times)$ $3 \mathrm{~g}$ soil subsamples of each flask with $15 \mathrm{~mL}$ of $\mathrm{H}_{3} \mathrm{PO}_{4}$ $0.35 \mathrm{~mol} \mathrm{~L}^{-1}$ by microwave-assisted solvent extraction (MASE) in microwave commercial apparatus at $800 \mathrm{~W}$ of power output in 5 cycles of $30 \mathrm{sec}$ each. The ${ }^{14} \mathrm{C}$-remnant and ${ }^{14} \mathrm{C}$-non-extractable residues were determined also by combustion of $(3 \times) 0.5 \mathrm{~g}$ soil samples of each flask, respectively before the extraction and after drying of the extraction solvent. The radiocarbon amounts were determined by LSC of $1.0 \mathrm{~mL}$ aliquots of the soil extracts and the total trap from combustions.

All the moist soil samples had the mass corrected for dry matter mass equivalent after determination of the water content in $(3 \times)$ approximately $3 \mathrm{~g}$ soil of each flask in a moisture analyzer.

The detected amounts of ${ }^{14} \mathrm{C}-\mathrm{CO}_{2},{ }^{14} \mathrm{C}$-remnant, ${ }^{14} \mathrm{C}$-extractable and ${ }^{14} \mathrm{C}$-non-extractable (or bound) residues were calculated as percentages of the total ${ }^{14} \mathrm{C}$ in the soil at the moment of the analysis and results were analyzed by the correlation coefficients (r) and statistical significance of the $t$ distribution $(\mathrm{p}<0.05)$ among the treatments. Halflives were calculated by the equation $\mathrm{Y}=\mathrm{y}_{0} \mathrm{e}^{\mathrm{kt}}$, in which $\mathrm{Y}$ is the percentage of $\left[{ }^{14} \mathrm{C}\right]$ as ${ }^{14} \mathrm{CO}_{2}$ or ${ }^{14} \mathrm{C}$-extractable in a time $\mathrm{t}$; $\mathrm{k}$ is the first-order decay constant $\left(\right.$ month $\left.^{-1}\right)$ and $\mathrm{y}_{0}$ is the theoretical maximal percentage of mineralization or extraction.

\section{Results and Discussion}

The ${ }^{14} \mathrm{C}$-glyphosate applied to soil was immediately mineralized since the first application, mainly in the first week after each treatment (Figure 1). The amounts mineralized in the first week after each application were $31.70 \pm 4.29 \%, 20.65 \pm 3.89 \%$, $22.03 \pm 1.02 \%$ and $14.50 \pm 0.99 \%$, respectively after 1 , 2, 3 and 4 treatments with ${ }^{14} \mathrm{C}$-glyphosate. This quick mineralization just after the application, as also found by Araújo et al. (2003), suggests that soil microorganisms are able to utilize glyphosate as a readily available $\mathrm{C}$ source as stated before by Krzysko-Lupicka \& Orlik (1997)

However, it is noteworthy that the immediate mineralization decreased significantly with the increasing number of treatments, with $\mathrm{p}$ values varying from 0.0011 (four applications) to 0.0037 (three applications) and 0.0389 (two applications). Feng \& Thompson (1990) and Cheah et al. (1998) had also detected initially rapid, followed by slower, degradation of glyphosate in soil and attributed,

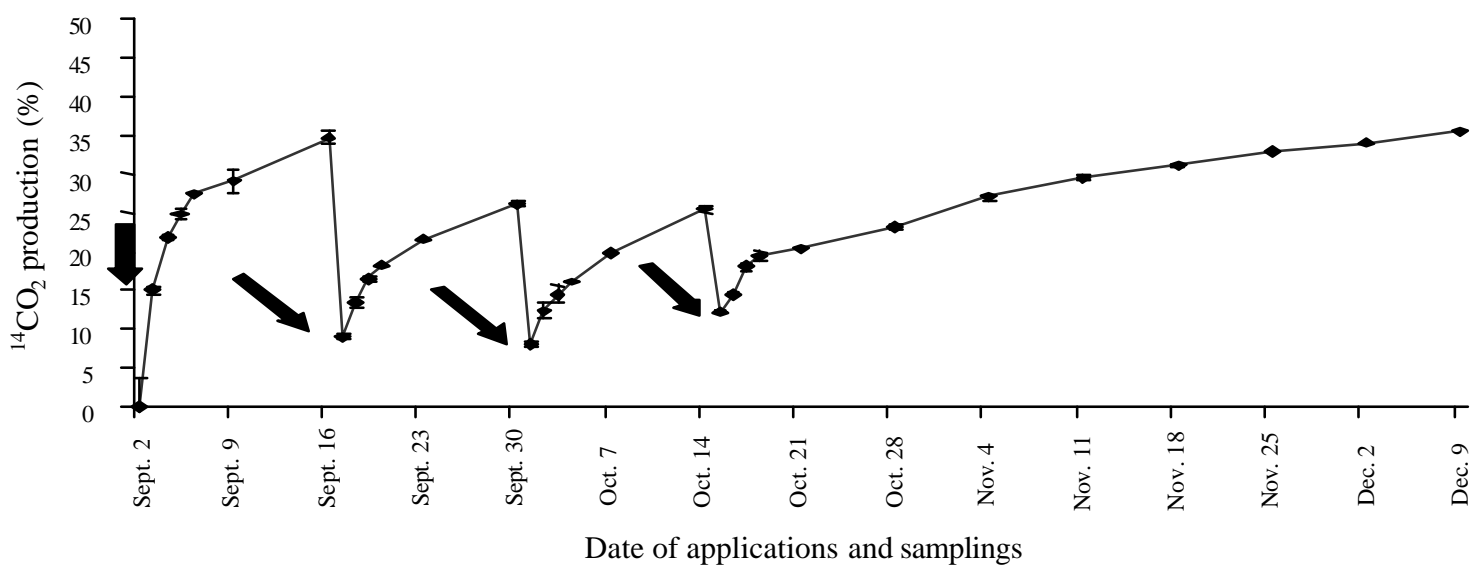

Figure 1. Production of ${ }^{14} \mathrm{CO}_{2}$ from ${ }^{14} \mathrm{C}$-glyphosate applied four times at fortnight intervals. Arrows indicate time of ${ }^{14} \mathrm{C}$-glyphosate application and vertical bars represent mean \pm standard deviations. 
respectively, to the initial action of microorganisms on the free glyphosate and subsequent attack to the herbicide adsorbed in the soil.

The ${ }^{14} \mathrm{C}$-glyphosate utilized is radiolabelled in the phosphonomethyl carbon, which is also present in the aminomethyl phosphoric acid (AMPA) molecule, that is the main metabolite of glyphosate. Thus, the detected amounts of ${ }^{14} \mathrm{CO}_{2}$ were formed from the degradation of glyphosate to AMPA, as well as from degradation of AMPA and express really total degradation of the pesticide molecule.

Further, the total amounts of ${ }^{14} \mathrm{CO}_{2}$ detected one or two months after the treatments also decreased with the higher number of ${ }^{14} \mathrm{C}$-glyphosate applications (Figure 2). The amount of ${ }^{14} \mathrm{CO}_{2}$ varied from approximately $47 \%$ (one application) to $33.5 \%$ (four applications), two months after treatments. These values are higher than those detected by Cheah et al. (1998). Araújo et al. (2003) found higher production of carbon dioxide from soils treated six years with glyphosate than from soils treated only one time. In that case, the applications might have selected the microbial populations able to utilize the herbicide. As ${ }^{14} \mathrm{CO}_{2}$ values detected two months after two, three and four applications were statistically smaller than after one application, it is clear that the soil microbial populations were really affected. Probably, the small time interval between applications did not allow the selection of microorganisms able to survive in presence of the herbicide. Although
${ }^{14} \mathrm{C}$-glyphosate or its ${ }^{14} \mathrm{C}$-metabolites were present in the soil (Figure 3), a biological change was detected because they were lesser biomineralized after the repeated applications.

No correlation was found between DHA-activity and ${ }^{14} \mathrm{CO}_{2}$ production. Results on DHA-activity for one or two months after glyphosate treatment were not statistically different from the amount of formazan detected before glyphosate treatments, which was $82.2 \pm 23.8 \mu \mathrm{g} \mathrm{g}^{-1}$ (Figure 4).

DHA-activity was stimulated ( $p$ value 0.0280 ) after two herbicide applications in relation to detection of DHA-activity after one application, which means that the herbicide might stimulate the soil oxidative process. Nevertheless, two months after glyphosate applications, there were no differences between the amounts of formazan, independently of treatment numbers, meaning that the herbicide effect on the enzyme activity was transient, as already found for other pesticides (Andréa et al., 2000). It seems that the glyphosate itself or its degradation products practically did not influence the activity of this enzyme in the soil studied. Sannino \& Gianfreda (2001) detected different responses of some soil enzymes of different soils treated with glyphosate.

Several extraction methods were tested but only the selected method resulted in $84.70 \pm 10.80 \%$ of extraction efficiency, and therefore results were corrected by this value. The amounts of

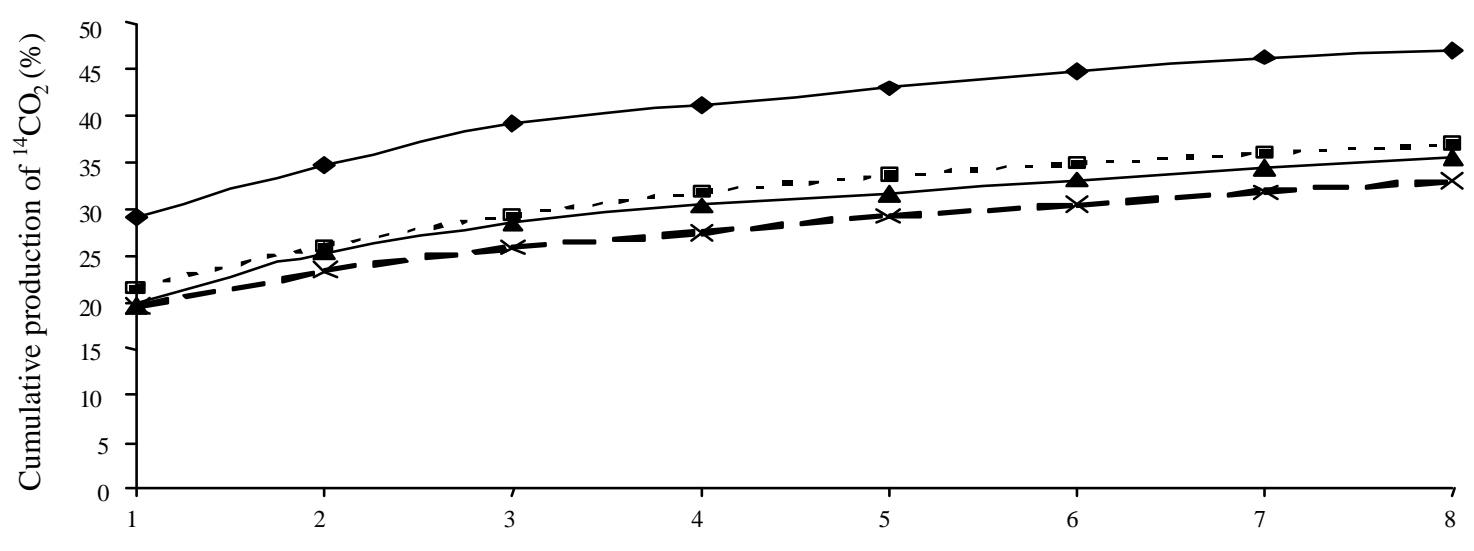

Time after the applications (weeks)

Figure 2. Mineralization of ${ }^{14} \mathrm{C}$-glyphosate after one $\left.\boldsymbol{\nabla}\right)$, two $(\boldsymbol{\square})$, three $(\boldsymbol{\Delta})$ and four $(\boldsymbol{X})$ repeated applications. 


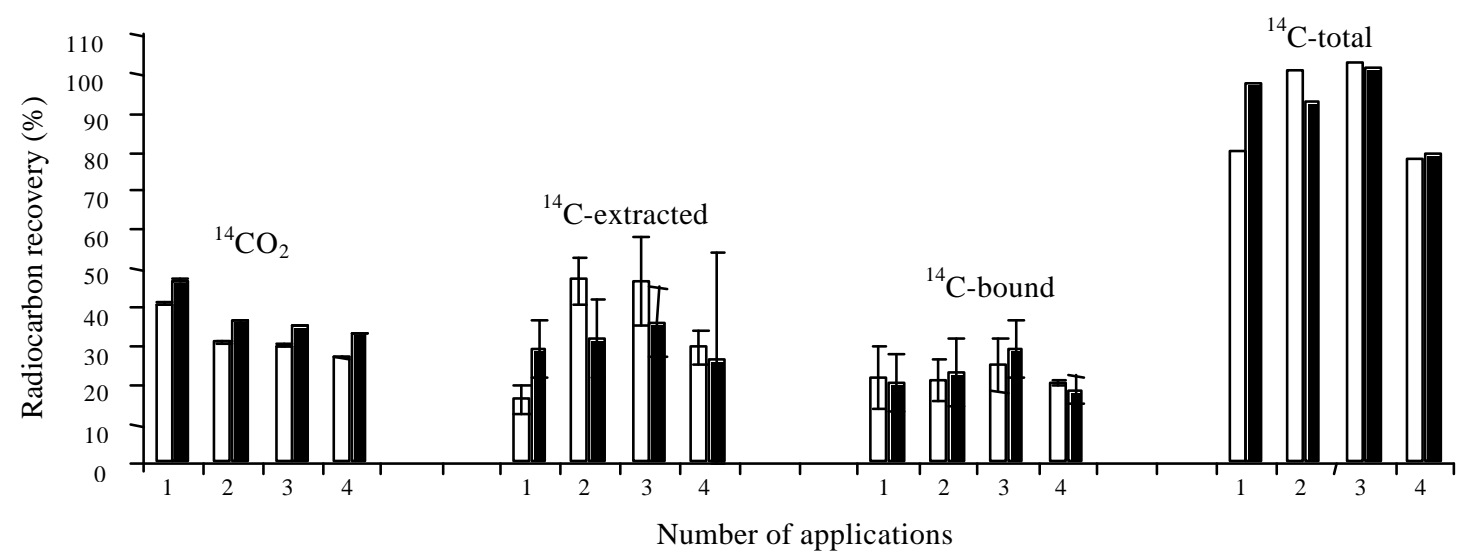

Figure 3. Radiocarbon recovery from ${ }^{14} \mathrm{C}$-glyphosate applied up to four times in soil, one ( $\square$ ) or two (匹) months after the applications. Vertical bars represent mean \pm standard deviations.

${ }^{14}$ C-extractable (Figure 3), i.e., the amounts of compounds readily available for action varied from nearly $17 \%$ (one application, one month) to $47 \%$ (two and three applications, one month). The amounts of ${ }^{14} \mathrm{C}$-non-extractable residues, which are the slow released residues because they depend on the microbial attack on the soil fraction where they are bound, varied from 19\% (four applications, two months) to $29.5 \%$ (three applications, two months). Finally, the balance of total radiocarbon recovered from ${ }^{14} \mathrm{C}$-glyphosate varied from $80 \%$ to $103 \%$ (Figure 3), which is in agreement with Cheah et al. (1998).

Logarithmic plots of the total ${ }^{14} \mathrm{C}$-extractable and ${ }^{14} \mathrm{CO}_{2}$ amounts versus time showed linear relationships ( $\mathrm{R}^{2}$ between 0.80 and 0.95 ) and halflives of glyphosate or other $\left[{ }^{14} \mathrm{C}\right]$-containing products, as AMPA, were calculated from these curves (Table 1). The half-lives of extractable residues varied little and the average was $0.92 \pm 0.29$ month, which shows the small persistence of the available residues and are near the Prata's (2002) results obtained with one glyphosate soil treatment. On the other hand, the half-lives of total mineralization increased with the number of ${ }^{14} \mathrm{C}$-glyphosate applications, i.e., 2.2, 3.0, 3.1 and 3.4 months, respectively after 1, 2, 3 and 4 applications. These values are higher than the Feng and Thompson's (1990) and Cheah's et al. (1998) values, and these differences can be attributed to the higher amount of organic matter of their soils, since it is known that

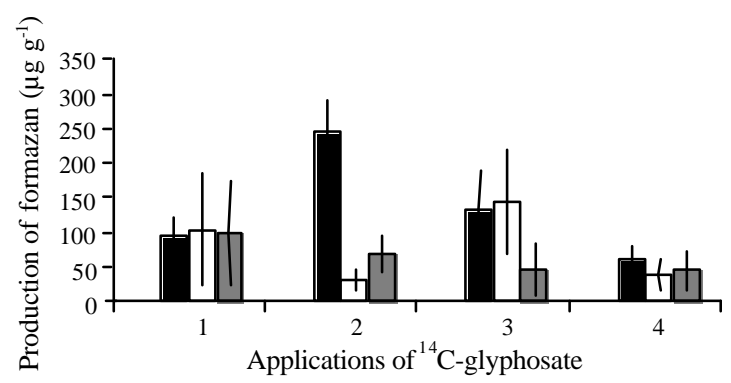

Figure 4. Soil dehydrogenase (DHA) activity immediately ( $\square$ ), one month $(\square)$ and two months ( $\square$ ) after applications of ${ }^{14} \mathrm{C}$-glyphosate.

Table 1. Half lives (months) of extractable and mineralized residues and correlation coefficients $\left(\mathrm{R}^{2}\right)$ of ${ }^{14} \mathrm{C}$-glyphosate applied up to four times in soil.

\begin{tabular}{|c|c|c|c|c|}
\hline \multirow{2}{*}{$\begin{array}{l}\text { Number of } \\
\text { applications }\end{array}$} & \multicolumn{2}{|c|}{ Extractable } & \multicolumn{2}{|c|}{ Mineralized } \\
\hline & Half-life & $\mathrm{R}^{2}$ & Half-life & $\mathrm{R}^{2}$ \\
\hline 1 & 0.50 & 1.0000 & 2.17 & 0.8705 \\
\hline 2 & 1.07 & 0.9471 & 3.00 & 0.8847 \\
\hline 3 & 1.18 & 0.9032 & 3.15 & 0.8781 \\
\hline 4 & 0.94 & 0.8044 & 3.40 & 0.8991 \\
\hline
\end{tabular}

soil microbial activity is highly dependent of the soil organic matter content.

Thus, the higher amount of the herbicide itself or its metabolites in the soil, the lesser metabolism would be expected. Feng \& Thompson (1990) had also detected rapid initial degradation, but detected glyphosate and AMPA residues up to 360 days after the herbicide application. Araújo et al. (2003) detected higher amounts of AMPA in glyphosate agriculturally 
treated soils than in soils treated only one time, which means that AMPA may be accumulated in soil and is more persistent than glyphosate. The decreasing tendency of the mineralized amounts, as well as the increasing half-lives values calculated from the ${ }^{14} \mathrm{CO}_{2}$ amounts with the increasing number of treatments, mean that repeated applications of glyphosate may result in gradual difficulty for soil metabolism of the total molecule.

\section{Conclusions}

1. The persistence of extractable and bound glyphosate residues formed is small.

2. Glyphosate biomineralization decreases with the increasing number of treatments, which indicates the effect on soil microbial activity.

\section{References}

ANDRÉA, M. M.; MATALLO, M. B.; TOMITA, R. Y.; LUCHINI, L. C. Effect of temperature on dissipation of $\left[{ }^{14} \mathrm{C}\right]$-atrazine in a Brazilian soil.Pesquisa Agropecuária Brasileira, Brasília, v. 32, n. 1, p. 95-100, jan. 1997.

ANDRÉA, M. M.; PAPINI, S.; NAKAGAWA, L. E. Optimizing microwave-assisted solvent extraction (MASE) of pesticides from soil. Journal of Environmental Science and Health, New York, v. B36, p. 87-93, 2001. ANDRÉA, M. M.; PERES, T. B.; LUCHINI, L. C.; PETTINELLI JUNIOR, A. Impact of long-term pesticide application on some soil biological parameters. Journal of Environmental Science and Health, New York, v. B35, p. 297-307, 2000.

ARAÚJO, A. S. F.; MONTEIRO, R. T. R.; ABARKELI, R. B. Effect of glyphosate on the microbial activity of two Brazilian soils. Chemosphere, Oxford, v. 52, p. 799-804, 2003.

AUBIN, A.; SMITH, A. E. Extraction of $\left[{ }^{14} \mathrm{C}\right]$ glyphosate from Saskatchewan soil. Journal of Agriculture and Food Chemistry, Washington, v. 40, p. 1163-1165, 1992.

BARTHA, R.; PRAMER, D. Features of a flask and method for measuring the persistence and biological effects of pesticides in soil. Soil Science, Baltimore, v. 100, p. 6870, 1965.

BRASIL. Ministério da Agricultura, Pecuária e Abastecimento. Departamento de Defesa e Inspeção Vegetal.Agrofit on line. Disponível em: <http:// masrv60.agricultura.gov.br/agrofit/>. Acesso em: 07 fev. 2003.
BROMILOW, R. H.; EVANS, A. A.; NICHOLLS, P. H. TODD, A. D.; BRIGGS, G. G. The effect on soil fertility of repeated applications of pesticides over 20 years. Pesticide Science, Chichester, v. 48, p. 63-72, 1996.

BUSSE, M. D.; RATCLIFF, A. W.; SHESTAK, C. J.; POWERS, R. F. Glyphosate toxicity and the effects of long-term vegetation control on soil microbial communities. Soil Biology and Biochemistry, Oxford, v. 33, p. 1777 1789, 2001.

CHEAH, U. B.; KIRKWOOD, R. C.; LUM, K. Y. Degradation of four commonly used pesticides in Malaysian agricultural soils. Journal of Agriculture and Food Chemistry, Washington, v. 46, p. 1217-1223, 1998.

ENVIRONMENTAL PROTECTION AGENCY (Washington, United States). Reregistration eligibility decision (RED): glyphosate. Available at: <http:// www.epa.gov/oppsrrd1/REDs/old_reds/glyphosate.pdf>. Accessed in: Feb. 07, 2003.

FENG, J. C.; THOMPSON, D. G. Fate of glyphosate in a Canadian forest watershed. 2: persistence in foliage and soils. Journal of Agriculture and Food Chemistry, Washington, v. 38, p. 1118-1125, 1990.

FRIGHETTO, R. T. S.; VALARINI, P. J. (Coord.). Indicadores biológicos e bioquímicos da qualidade do solo. Jaguariúna: Embrapa-CNPMA, 2000. p. 37-40.

HANEY, R. L.; SENSEMAN, S. A.; HONS, F. M.; ZUBERER, D. A. Effect of glyphosate on soil microbial activity and biomass. Weed Science, Champaign, v. 48, p. 89-93, 2000.

HEINONEN-TANSKI, $\mathrm{H}$. The effect of temperature and liming on the degradation of glyphosate in two artic forest soils. Soil Biology and Biochemistry, Oxford, v. 21, p. 313-317, 1989.

KRZYSKO-LUPICKA, T.; ORLIK, A. The use of glyphosate as the sole source of phosphorus or carbon for the selection of soil-borne fungal strains capable to degrade this herbicide. Chemosphere, Oxford, v. 34, p. 26012605, 1997.

MESQUITA, T. B.; RÜEGG, E. F. Influência de agentes tensoativos na detecção da radiação beta. Ciência e Cultura, São Paulo, v. 36, p. 446-450, 1984.

PAPINI, S.; ANDRÉA, M. M. Enhanced degradation of metalaxyl in Gley Humic and Dark Red Latosol. Revista Brasileira de Ciência do Solo, Viçosa, MG, v. 4, p. 469474, 2000. 
PRATA, F. Comportamento do glifosato no solo e deslocamento miscível de atrazina. 2002. 149 p. Tese (Doutorado em Solos e Nutrição de Plantas) - Universidade de São Paulo, São Paulo, 2002.

SANNINO, F.; GIANFREDA, L. Pesticide influence on soil enzymatic activities. Chemosphere, Oxford, v. 45, p. 417-425, 2001.

SCHUSTER, E.; SCHRÖDER, D. Side-effects of sequentially-applied pesticides on non-target soil microorganisms: field experiments. Soil Biology and Biochemistry, Oxford, v. 22, p. 375-383, 1990.

SOUZA, A. P.; FERREIRA, F. A.; SILVA, A. A.; CARDOSO, A. A.; RUIZ, H. A. Respiração microbiana do solo sob doses de glyphosate e de imazapyr. Planta Daninha, Viçosa, MG, v. 17, p. 387-398, 1999a.

SOUZA, A. P.; PRATES, H. T.; FERREIRA, F. A.; REIS, E. L.; JORDÃO, C. P. Lixiviação do glyphosate e do imazapyr em solos com diferentes texturas e composição química - II: método analítico. Planta Daninha, Viçosa, MG, v. 17, p. 245-262, 1999b.
SPRINGETT, J. A.; GRAY, R. A. J. Effect of repeated low doses of biocides on the earthworm Aporrectodea caliginosa in laboratory culture. Soil Biology and Biochemistry, Oxford, v. 24, p. 1739-1744, 1992.

VEIGA, F.; ZAPATA, J. M.; MARCOS, M. L. F.; ALVAREZ, E. Dynamics of glyphosate and aminomethylphosphonic acid in a forest soil in Galicia, north-west Spain. Science of the Total Environment, Amsterdam, v. 271, p. 135-144, 2001.

WARDLE, D. A.; NICHOLSON, K. S.; RAHMAN, A. Influence of herbicide applications on the decomposition, microbial biomass, and microbial activity of pasture shoot and root litter. New Zealand Journal of Agricultural Research, Wellington, v. 37, p. 29-39, 1994.

WEBER, J. B. Properties and behavior of pesticides in soil. In: HONEYCUTT, R. C.; SCHABACKER, D. J. (Ed.). Mechanisms of pesticide movement into ground water. London: Lewis, 1994. p. 15-41.

WORTHING, C. R.; HANCE, R. J. The pesticide manual. $9^{\text {th }}$ ed. Surrey: British Crop Protection Council, 1991. p. 554-555. 